\title{
Reflections on the Promotion of Farmers' Ecological Consciousness at This Stage
}

\author{
Xiao Ning Yang ${ }^{1, *}$, Min Zhang ${ }^{2}$ \\ ${ }^{1}$ Professor, School of Marxism, Dalian University, Dalian, Liaoning, China \\ ${ }^{2}$ Graduate student, School of Marxism, Dalian University, Dalian, Liaoning, China \\ *Email: xiaoningdl@163.com
}

\begin{abstract}
General Secretary Xi Jinping stresses the importance of unswervingly promoting the harmonious co-existence of man and nature to ensure the sustainable development of the Chinese nation for generations to come. Farmers account for the majority of the population in China. They are not only the main body of agricultural and rural development, but also the key to realize the harmonious coexistence between man and nature. Therefore, it is of great significance to enhance farmers' ecological awareness for the construction of ecological civilization in China. However, at the present stage, the ecological consciousness of Chinese farmers generally lags behind, and there is a distance with the development requirements of the party and the country. Therefore, more efforts should be made in the aspects of ecological value, ecological morality, ecological responsibility and ecological technology, so as to better promote the building of a beautiful China.
\end{abstract}

Keywords: farmer, ecological consciousness, harmonious coexistence between man and nature

\section{FARMERS ARE THE KEY TO REALIZE THE HARMONIOUS COEXISTENCE BETWEEN MAN AND NATURE}

The construction of ecological civilization is related to the well-being of the people's livelihood. As for the future of the nation, it is a millennium plan for the lasting and sustainable development of the Chinese nation. The 17th National Congress of the Communist Party of China put forward the goal of ecological civilization construction for the first time. Promoting ecological civilization construction is not only an urgent requirement, but also a guarantee to achieve higher requirements. The 18th National Congress of the Communist Party of China incorporated the construction of ecological civilization into the fivesphere integrated plan for the cause of socialism with Chinese characteristics. The 14th Five-Year Plan also points out that we should further implement the sustainable development strategy, build an ecological civilization system, and build a modernization in which man and nature coexist harmoniously. All these reflect the great importance the CPC Central Committee attaches to the construction of ecological civilization. The fundamental principle of the construction of ecological civilization is to realize the harmonious coexistence between man and nature, among which an important link is the construction of ecological civilization in rural areas. China is a traditional agricultural country, and surveys show that rural pollution emissions account for nearly half of the national pollution emissions, so rural ecological problems are the focus of ecological civilization construction. To realize the coordinated development of man and nature in rural areas, we must enhance the ecological consciousness of farmers, because farmers account for the majority of the population and are the main force and key to the construction of rural ecological civilization. Enhancing farmers' ecological consciousness is the driving force and source of rural ecological civilization construction. Leopold, an American scholar, believes that without ecological awareness, obligations beyond self-interest are empty words. So the problem we are facing is to extend the scale of social consciousness from human beings to nature. The author clings to the perspective that human behavior is guided by human consciousness. Therefore, the construction of ecological civilization is the first to cultivate "ecological people". Only by cultivating and improving farmers' ecological consciousness can we lay a solid foundation for the construction of rural ecological civilization, and be conducive to the 
construction of rural ecological community of Shared future, and promote the sustainable development of China's economy. Enhancing farmers' ecological consciousness is the basis and premise of promoting rural revitalization strategy. Rural revitalization is omnidirectional. If the countryside is not beautiful, all the strategies of strengthening agriculture and enriching peasants are empty talk. We must put the basic state policy of resource conservation and environmental protection into the whole process of rural revitalization; improve farmers' ecological consciousness from beginning to end, and walk out a new socialist countryside construction road of production development, rich life, civilized village style, tidy village appearance, and democratic management.

\section{AT PRESENT, THE ECOLOGICAL CONSCIOUSNESS OF CHINESE FARMERS GENERALLY LAGS BEHIND}

Since the 18th National Congress of the Communist Party of China, the CPC Central Committee has attached great importance to ecological and environmental issues, called for the idea that clear water and lush mountains are invaluable assets, and made great efforts to promote ecological progress. Efforts were made to conserve resources across the board; the intensity of energy and resources consumption has reduced significantly; major ecological protection and restoration projects are progressing smoothly; forest coverage continues to increase; ecological environment governance has been notably strengthened; environmental conditions have been improved. People across the country are becoming more conscious and proactive in implementing the concept of green development. In the past, the situation of neglecting ecological and environmental protection, such as focusing only on immediate interests, developing first and then harnessing, exchanging green water and green mountains for gold and silver mountains, has been significantly improved. In particular, the number of farmers who actively curb their own non-environmental protection behaviors has gradually increased. Although farmers' recognition, attention and participation in the construction of ecological civilization have been improved to a certain extent, due to the low level of education, uneven cultural level, inadequate government publicity and limited social environment, there are still many unsatisfactory aspects of farmers' ecological consciousness, and the construction of rural ecological civilization has a long way to go.

The main manifestations of the lack of ecological consciousness of farmers are as follows: Firstly, the positioning of farmers' ecological value consciousness is not high, and lack of the overall view of sustainable development. ${ }^{[1]}$ Ecological value consciousness refers to "people's pursuit of ecological environment value and the value scale of ecological environment utilization in dealing with the relationship between human and nature." ${ }^{[2]}$ Natural resources are limited, and the rational use of natural resources is a necessary condition for the normal development of human society. As Karl Marx pointed out, we should reasonably regulate the material exchange between man and nature. This kind of material exchange should be carried out under the conditions most worthy of and most suitable for human nature. However, quite a number of farmers are still far from understanding the interdependence between human and nature from the perspective of human and natural life community. In real life, they often give priority to their own interests and exploit natural resources in a predatory way. They only focus on demand, not investment; only utilization, not construction; only short-term interests, regardless of long-term interests. Just as Mahatma Gandhi said, "Earth provides enough to satisfy man's need, but not every man's greed." If this "Paradox of the Pasture" situation is not changed, nature will inevitably retaliate against human beings, and human development will be unsustainable. Secondly, the lack of ecological moral consciousness of farmers, moral anomie behaviors occur from time to time. Ecological moral consciousness refers to "people's understanding of the overall laws and operational significance of the ecosystem when dealing with the relationships between people, people and society, and people and nature. It is the most direct reflection of ecological moral relationship in real life, at the first level of the generative logic of ecological morality, and is the foundation of the generation of ecological morality. " ${ }^{[3]}$ However, due to geographical and cultural constraints, farmers tend to focus on their own interests, and some village-run enterprises fail to meet environmental standards, resulting in the development of high pollution and energy consuming industries at the expense of the environment. Within the scope of nature reserves and wetland parks in some places, illegal sand mining, disorderly breeding, pollution discharge, overgrazing and other phenomena that damage Lake Wetland resources still exist. In addition, due to the lack of ecological moral consciousness, it is not uncommon for poultry excrement to be dumped at will and domestic garbage to be thrown everywhere. Thirdly, the lack of awareness of ecological responsibility caused by the absence of civic awareness. ${ }^{[4]}$ Civic consciousness refers to the individual citizen's self-awareness of his or her status in the country. Limited by the level of education, many people in rural areas lack a sense of citizenship, and let alone talk about social responsibility and social mission. In their opinion, as long as their own land is planted well, environmental protection is a matter for the government and village cadres. Therefore, they allow the phenomenon of environmental damage to happen around them with a kind of indifferent and lofty attitude...According to Marxism, the essence of man is the sum total of social relations in its reality. We have only one home, the earth. When the environment is 
destroyed, no one can be immune. Therefore, everyone is responsible for protecting the environment. Only when everyone undertakes his own ecological responsibility and mission, can we protect the environment we live on. Fourthly, farmers lack of knowledge of ecological environmental protection, and their environmental protection skills are not high. In order to reduce the labor force, most farmers use the way of spraying pesticides to eliminate pests; in order to facilitate, they burn straw to deal with garbage; they use chemical fertilizer to improve the yield, and hold the mentality of "more is better than less"; they cover plastic film to make the products go on the market early. Nevertheless, they do not know that this traditional way of production will damage the ecological environment. And they formed a stereotype of agricultural production without environmental pollution. In fact, excessive spraying of pesticides will pollute water, soil and atmosphere; excessive use of chemical fertilizers will lead to a large number of saline alkali land and hardened land, which will bury hidden dangers for environmental deterioration; and so on. Therefore, guiding farmers to use scientific and technological means for production is conducive to the sustainable development of rural economy. ${ }^{[5]}$

\section{SUGGESTIONS ON IMPROVING FARMERS' ECOLOGICAL CONSCIOUSNESS}

First of all, from the long-term interests of farmers, improving the ecological value orientation of farmers. We can take the method of ecological values education to guide farmers to correctly understand that man and nature are a community of common destiny. To begin with, the government should increase capital investment in the construction of infrastructure, such as publicity boards, rural libraries, etc. Environmental protection and health publicity column can be used in the form of a combination of cartoon and text, showing some cases that human beings cannot survive because of the destruction of the environment. The vivid cartoons are easy to attract the attention of farmers and easy to understand. After the establishment of the rural library, village cadres can organize villagers to carry out regular reading activities to read more books on Chinese excellent traditional culture. For example, Confucianism has been convinced that "heaven" is the nature of independent operation law, and man is an existence in the natural order. All the existences are interdependent and form a whole. The villagers discuss what they read and express their own opinions. Inspired by the village cadres, famers come to the correct conclusion that man and nature are interlinked, harmonious and coprosperous. After the activity, awards will be given based on individual reading situation and performance, and all the villagers who participate in the reading activities will be given Memorial Prizes, which can not only fully mobilize the enthusiasm of the villagers, but also arouse the villagers' awareness of environmental protection. What's more, local village committees set up institutions to educate farmers on ecological values. Village committees employ rural environmental protection experts to publicize ecological and environmental protection knowledge through regular and irregular centralized teaching, publicizing the ecological awareness that environmental protection is of great benefit to the present and future generations. In view of the confusions and problems encountered by the villagers in the process of receiving values education, experts should go deep into the farmers for special guidance. Last but not least, the content of "environmental protection education" should be permeated into the education of various subjects in the primary schools of each village. Guiding children to publicize the knowledge that environmental protection is not only conducive to the current development, but also conducive to the survival and development of future generations to their parents, relatives and neighbors, so that farmers gradually develop the concept of "protecting the environment and benefiting future generations". Leading famers to respect nature, conform to nature and protect nature with a highly responsible attitude and responsibility for future generations. Striving to create a good working and living environment for future generations and keeping the clear water, green mountains, blue sea and blue sky for future generations.

Next, from the details of life around us, improving the ecological moral awareness of farmers. The first is to strengthen institutional construction and use institutions to restrain villagers' behaviors. ${ }^{[6]}$ For instance, we should formulate a series of relevant laws, regulations and policies, such as the Environmental Protection Law, the Law on the Prevention and Control of Environmental Pollution by Solid Waste, and the Opinions on Accelerating the Construction of Ecological Civilization. The township enterprises that still adopt the production mode of "mass production, mass consumption and mass emission" that fail to meet the standards shall be punished administratively; the villages that fail to protect the environment shall be notified and held accountable, and the serious cases can be traced back to the specific villagers and punished, forming the situation of "not daring to pollute the environment". The second is to form an "environmental protection promotion association" elected by the villagers to lead the environmental protection work of the whole village, so that the major polluters are always under the supervision of the villagers; for any production behavior that may cause damage to the environment, experts should be invited to give their opinions before deciding whether to do it. Each household should establish a garbage bin, and store the waste in the designated garbage bin. The garbage is 
collected in groups and sent to the township garbage transfer station for treatment after being concentrated in the village garbage station, forming a situation of "not polluting the environment". The third is to give full play to the main role of the villagers, and widely solicit the opinions of the villagers in accordance with the principle of consultation and joint construction. Each village formulates its own village rules and regulations in line with its actual situation, implements selfmanagement and consciously abides by them. To demonstrate, we should consciously clean up our own heaps of soil, dung and firewood, and put firewood on the firewood stacking yard, and go to the grain drying yard when drying grain, so as to form a situation of "not wanting to pollute the environment". Starting from these trivial things which are closely related to farmers' lives, we should guide farmers to improve their initiative and consciousness in protecting the ecological environment, and form a social atmosphere and ecological moral consensus in the whole society that "protecting the environment is glorious, polluting the environment is shameful".

Then, starting from the cultivation of civic awareness, improving the ecological responsibility awareness of farmers. First, we will further develop the socialist market economy. Under the smallholder peasant economy, we can only cultivate the "dependent people" who are lack of independent personality and subjective consciousness and highly dependent on power. ${ }^{[7]}$ Vigorously developing rural market economy is the basis of breaking the farmers' smallholder consciousness. We should formulate a fair, orderly, open and transparent mechanism to enable peasant households, rural economic cooperation organizations and township enterprises to participate in market competition on an equal basis. We should foster an open market system for agricultural products, making the exchanges between villages and regions unimpeded, guiding farmers to form the awareness of cooperation, fairness and integrity in trade, and arousing their sense of citizenship. The second is to strictly abide by the Law on Villagers' Committee Autonomy. The power of selfmanagement, self-education and self-service of villagers' committees shall be guaranteed, and the rights of villagers to participate in democratic election, decision-making, management and supervision shall be safeguarded. As an illustration, before the election of the person in charge of the construction of rural ecological civilization, we should do a good job of publicity, making farmers aware of the significance of the election, adopting an open and transparent way of voting, selecting cadres with strong environmental awareness, and imperceptibly cultivating farmers' subjective consciousness through this process. In addition, village officials should ensure smooth network, petition, hearing and other channels to ensure that farmers can express their ecological interests, and they should respect the wishes of farmers. at the same time, the environmental protection volunteer team, breeding professional association and other nongovernmental organizations should be established, so that each villager can realize that he has the right and obligation to participate in public affairs in the activities, and realize that environmental protection is his duty, so as to take the initiative to undertake the responsibility of environmental protection.

Finally, from the cultivation, breeding technology training, improving the ecological and environmental protection knowledge of farmers. First, through the introduction of preferential policies, improving living conditions, improving the working environment and other measures to attract agriculture-related talents and graduates with higher comprehensive quality to carry out agricultural technology popularization. Agricultural technology training personnel should take the lead in mastering agricultural ecological technology, and regularly carry out knowledge and skills assessment to urge them to constantly improve themselves. Second, excellent technicians through the combination of online and offline training mode, using classroom training or through the public number consultation, QQ WeChat group and so on to grasp the universal training. Through scientific and technological knowledge consultation and practical technical training to improve famers' scientific and cultural quality. We should teach students according to their aptitude and ensure that at least one person in each village or household master practical technology. To illustrate, in the aspect of planting, farmers should be advocated to use organic fertilizer for a long time to prevent and reduce environmental pollution. Skillers should use easy-to-understand language to explain the benefits of regular application of organic fertilizer to farmers. For example, organic fertilizer can increase the content of organic matter in the soil, greatly improve the adsorption capacity of the soil, and remove toxic substances in the soil. Farmers are encouraged to use biopesticides. The effective components of biopesticides exist completely or originate from nature. Therefore, they have good environmental compatibility and no pollution. After the ecological technology is taught to farmers, the trainers should go to villages and households for demonstration. For example, in the aspect of aquaculture, technicians personally demonstrat the "zero emission" aquaculture technology, proving that it can completely solve the problem of aquaculture pollution. "Face to face" and "hand to hand" ecological technology zero distance guidance will be implemented. The third is to set up agricultural service hotline to provide expert technical consultation service for farmers, and answer questions and solve doubts for farmers in time, so that farmers have rules to follow in the production process. In this way, farmers not only learn ecological techniques, but also increase the 
knowledge of environmental protection. This process also injects environmental awareness into farmers.

\section{CONCLUSION}

The Fifth Plenary Session of the 19th CPC Central Committee pointed out that the goal of building a beautiful China will be basically realized by 2035, which requires the whole society to spare no effort in the construction of ecological civilization. It should be pointed out that China's rural area is vast and the population is relatively large. Ecological civilization construction in rural areas plays a leading role in realizing the goal of "Beautiful China". However, it is undeniable that the ecological awareness of Chinese farmers is still weak at the current stage, which greatly affects the promotion of ecological civilization construction in China. Therefore, actively exploring the crux of farmers' ecological awareness, making efforts to take effective measures, persistently improving farmers' ecological awareness to promote green development and harmonious coexistence between man and nature is a great cause that benefits both the present and the future, which requires the joint efforts of all the people to build a beautiful China.

\section{REFERENCES}

[1] Yan Xifeng, On the Consciousness of Ecological Civilization, Theoretical Discussion, 2008 (6), pp. 65-68. DOI: 10.3969/j.issn.1000-8594. 2008. 06. 016.

[2] Chen Chunyan, Wang Yishan, Study on the Ecological Consciousness of Contemporary Farmers, Jilin Agriculture, 2012(6), 7. DOI: 10.3969/j.issn.1674-0432.2012.06.007.

[3] Nong Chunshi, The Connotation, Cultivation and Cultivation Path of Citizen Ecological Morality, Journal of Jiangsu University (Social Science Education), 2020(6), 44. DOI: 10.13317/ j.cnki.jdskxb.2020.059

[4] Liu Xiangrong, On Ecological Consciousness, Qiu Suo, 1994(2), pp. 56-61 . DOI: 10.16059/j.cnki.cn43-1008/c.1994.02.014

[5] Jiang Chunyun, Leading Sustainable Development of Agriculture with Ecological Civilization, Qiu Shi, 2011 (22), pp. 50 -52.

[6] Wang Jiye, Study on the Problems and Countermeasures of Rural Ecological Environment in China, Anhui Agricultural Science, 2007(23), pp. 7241-7242. DOI: 7241-7242. doi: 10.3969/j.issn.0517-6611.2007.23.095.

[7] Li Chen, The Cultivation of Rural Ecological Consciousness from the Perspective of New Rural
Construction, Journal of Shandong Agricultural Management Cadre College, 2012(3), pp. 7-9. DOI: 10.15948/j.cnki.37-1500/s.2012.03.001 